\title{
GORESAN SYAIR PURNOMO
}

\section{Ela Nur Laliyah}

Universitas Nahdlatul Ulama Sidoarjo

\section{PENDAHULUAN}

Puisi merupakan genre sastra yang terkait dengan versifikasi dan tunduk pada aturan prosodik tertentu, bervariasi sesuai dengan budaya dan waktu, tetapi selalu cenderung menekankan ritme, harmoni, dan gambar. Bagaimana puisi menyentuh musik oleh prosodi yang akarnya menjerumuskan lebih dalam ke jiwa manusia daripada yang ditunjukkan teori klasik mana pun. Puisi bukan satu-satunya bidang di mana simbolisme suara membuat efeknya terasa, tetapi itu adalah provinsi di mana hubungan antara suara dan makna, laten, menjadi paten, dan memanifestasikan dirinya dengan cara yang paling jelas. dan yang paling intens. Puisi adalah ekspresi penderitaan yang 
dikunci dalam lingkaran tanpa jalan keluar: dalam kata kerja, ia tidak lagi berharap menemukan keselamatan, tetapi hanya kemungkinan nuansa. Ini menegaskan dirinya sebagai manifestasi tertinggi dan paling murni dari penciptaan sastra: ia masuk ke dalam oposisi dengan sisa literatur dan, tanpa cadangan atau batas, arrogated untuk dirinya sendiri kebebasan untuk mengatakan segala sesuatu yang diilhami oleh imajinasi yang angkuh, suatu interioritas meluas ke ukuranukuran ketidaksadaran dan akhirnya permainan dalam transendensi yang tidak lagi merujuk pada apa pun (CNRTL, 2019).

Puisi juga sebagai seni untuk membangkitkan dan menyarankan sensasi, kesan, emosi yang paling jelas oleh penyatuan suara, ritme, harmoni, terutama oleh penyair. Genre puisi : Puisi lirik, epik, heroik. Seni puisi khususnya untuk seorang penyair, untuk suatu bangsa, pada suatu waktu (Larousse, 2019). 
Beberapa manfaat puisi menurut Avanzi (2014) diantaranya yaitu:

1. Puisi adalah seni imajiner utopis yang melampaui kenyataan untuk membuka jalan bagi potensi kreatif kita yang tak terbatas

2. Puisi adalah seni terapi yang kuat dan dalam terapi musik, seperti pantulan cermin, pada akhirnya, itu adalah seni yang menerangi jiwa (lihat perjalanan internal musik Odyssey Manusia) .

3. Puisi menerjemahkan melodi seni kehidupan untuk menciptakan simfoni masa depan dalam lagu tentang kemungkinan pada kanvas bumi yang tidak terlihat oleh bintangbintang

4. Puisi menyatukan suara-suara hati, intuisi, emosi, dan nalar dalam perkembangan cinta, kebaikan, berbagi, dan kebahagiaan semua orang.

5. Puisi adalah perjalanan yang mengangkut kita dalam ruang dan waktu. Jalan memutar di masa lalu, kembali ke masa depan, 
keharmonisan hutan dengan kegilaan hari esok, jadi jika alam semesta itu satu, maka kita hanya bisa menjadi rendah hati.

\section{SANG PENYAIR}

Tulisan ini mengulas goresan penyair bernama lengkap Agung Purnomo dan tumbuh di Sidoarjo. Berikut tulisan syair beliau telah disebarkan secara luas melalui penerbit nasional, yaitu: STIEBA Madura Press, dan UNUSIDA Press. 


\section{Tabel 1. Syair Kreasi Agung Purnomo}

\begin{tabular}{|c|c|c|c|c|c|c|}
\hline No & $\begin{array}{l}\text { Judul } \\
\text { Puisi }\end{array}$ & $\begin{array}{l}\text { Jenis } \\
\text { puisi }\end{array}$ & $\begin{array}{l}\text { Judul } \\
\text { buku }\end{array}$ & Penulis & Tahun & Penerbit \\
\hline 1 & $\begin{array}{l}\text { Rindu di } \\
\text { Ubun- } \\
\text { Ubun }\end{array}$ & $\begin{array}{l}\text { Puisi } \\
\text { Bebas }\end{array}$ & $\begin{array}{l}\text { Rassana } \\
\text { Jlantir }\end{array}$ & $\begin{array}{l}\text { Agung } \\
\text { Purnomo }\end{array}$ & 2019 & $\begin{array}{c}\text { STIEBA } \\
\text { Madura } \\
\text { Press }\end{array}$ \\
\hline 2 & Pandai & $\begin{array}{l}\text { Puisi } \\
\text { Riddle }\end{array}$ & $\begin{array}{c}\text { Tolesan } \\
\text { Aditi }\end{array}$ & $\begin{array}{c}\text { Agung } \\
\text { Purnomo, } \\
\text { Nur Asitah }\end{array}$ & 2019 & $\begin{array}{c}\text { STIEBA } \\
\text { Madura } \\
\text { Press }\end{array}$ \\
\hline 3 & Berpulang & $\begin{array}{l}\text { Puisi } \\
\text { epitaf }\end{array}$ & $\begin{array}{c}\text { Syair } \\
\text { Nimala }\end{array}$ & $\begin{array}{l}\text { Agung } \\
\text { Purnomo }\end{array}$ & 2019 & $\begin{array}{c}\text { STIEBA } \\
\text { Madura } \\
\text { Press }\end{array}$ \\
\hline 4 & $\begin{array}{c}\text { Bapak } \\
\text { Samsuri }\end{array}$ & $\begin{array}{c}\text { Puisi } \\
\text { Clerihew }\end{array}$ & $\begin{array}{c}\text { Dhalubang } \\
\text { Marta }\end{array}$ & $\begin{array}{l}\text { Agung } \\
\text { Purnomo, } \\
\text { Nur Asitah }\end{array}$ & 2019 & $\begin{array}{c}\text { STIEBA } \\
\text { Madura } \\
\text { Press }\end{array}$ \\
\hline 5 & Dua Kaki & $\begin{array}{l}\text { Puisi } \\
\text { Bebas }\end{array}$ & $\begin{array}{l}\text { Kidung } \\
\text { Nawala } \\
\text { (Jilid 2) }\end{array}$ & $\begin{array}{l}\text { Agung } \\
\text { Purnomo }\end{array}$ & 2018 & $\begin{array}{l}\text { UNUSIDA } \\
\text { Press }\end{array}$ \\
\hline 6 & Tangisnya & $\begin{array}{l}\text { Puisi } \\
\text { Naratif }\end{array}$ & $\begin{array}{c}\text { Bhumi } \\
\text { Bawera }\end{array}$ & $\begin{array}{l}\text { Agung } \\
\text { Purnomo, } \\
\text { Nur Asitah }\end{array}$ & 2019 & $\begin{array}{c}\text { STIEBA } \\
\text { Madura } \\
\text { Press }\end{array}$ \\
\hline 7 & $\begin{array}{l}\text { Sepekan } \\
\text { Awal } \\
\text { Tanpamu }\end{array}$ & $\begin{array}{l}\text { Puisi } \\
\text { bersekuen }\end{array}$ & $\begin{array}{l}\text { Arebhan } \\
\text { Helai }\end{array}$ & $\begin{array}{l}\text { Agung } \\
\text { Purnomo, } \\
\text { Nur Asitah }\end{array}$ & 2019 & $\begin{array}{c}\text { STIEBA } \\
\text { Madura } \\
\text { Press }\end{array}$ \\
\hline 8 & Cantik & $\begin{array}{l}\text { Puisi } \\
\text { Jenaka } \\
\text { Limerick }\end{array}$ & $\begin{array}{l}\text { Lembhar } \\
\text { Jiwana }\end{array}$ & $\begin{array}{l}\text { Agung } \\
\text { Purnomo, } \\
\text { Nur Asitah }\end{array}$ & 2019 & $\begin{array}{c}\text { STIEBA } \\
\text { Madura } \\
\text { Press }\end{array}$ \\
\hline 9 & Menyala & $\begin{array}{l}\text { Puisi } \\
\text { Haiku }\end{array}$ & $\begin{array}{l}\text { Tenta } \\
\text { Kimaya }\end{array}$ & $\begin{array}{l}\text { Agung } \\
\text { Purnomo }\end{array}$ & 2019 & $\begin{array}{c}\text { STIEBA } \\
\text { Madura } \\
\text { Press }\end{array}$ \\
\hline 10 & Kita & $\begin{array}{l}\text { Puisi } \\
\text { Bebas }\end{array}$ & $\begin{array}{l}\text { Suweda } \\
\text { Ate }\end{array}$ & $\begin{array}{l}\text { Agung } \\
\text { Purnomo, } \\
\text { Elsa } \\
\text { Rosyidah }\end{array}$ & 2019 & $\begin{array}{c}\text { STIEBA } \\
\text { Madura } \\
\text { Press }\end{array}$ \\
\hline 11 & $\# \mathrm{CH} 1$ & $\begin{array}{l}\text { Puisi } \\
\text { Bebas }\end{array}$ & $\begin{array}{l}\text { Kidung } \\
\text { Nawala } \\
\text { (Jilid 1) }\end{array}$ & $\begin{array}{l}\text { Agung } \\
\text { Purnomo }\end{array}$ & 2018 & $\begin{array}{l}\text { UNUSIDA } \\
\text { Press }\end{array}$ \\
\hline
\end{tabular}




\section{ULASAN SYAIR}

Berikut beberapa syair gubahan Agung Purnomo yakni: rindu di ubun-ubun (Purnomo, 2019c), sepekan awal tanpamu (Purnomo \& Asitah, 2019d), \#CH1 (Purnomo, 2018a), cantik (Purnomo \& Asitah, 2019b), berpulang (Purnomo, 2019a), dua kaki (Purnomo, 2018b), bapak Samsuri (Purnomo \& Asitah, 2019a), menyala (Purnomo, 2019b), tangisnya (Purnomo \& Asitah, 2019e), pandai (Purnomo \& Asitah, 2019c), dan kita (Purnomo \& Rosyidah, 2019).

Setidaknya Agung Purnomo telah menyusun sebelas puisi dengan gaya epitaf, clerihew, bebas, riddle, bersekuen, jenaka limerik dan haiku. Puisi diterbikan pada periode tahun 2018 dan tahun 2019. Sangat direkomendasikan untuk membaca karya-karya puisi beliau. 


\section{REFERENCES}

Avanzi, V. (2014). Les 10 vertus de l'art qui sublime l'âme. Retrieved June 20, 2019, from https://odysseehumaine.com/2014/06/26/pourqu oi-faire-de-la-poesie-les-10-vertus-de-lart-quisublime-lame/

CNRTL. (2019). Poésie. Retrieved June 27, 2019, from https://www.cnrtl.fr/definition/poésie

Larousse. (2019). Poésie. Retrieved June 25, 2019, from

https://www.larousse.fr/dictionnaires/francais/po ésie/61960

Purnomo, A. (2018a). \#CH1. In Kidung Nawala (Jilid

1). Sidoarjo: UNUSIDA Press.

Purnomo, A. (2018b). Dua Kaki. In Kidung Nawala (Jilid 2). Sidoarjo: UNUSIDA Press.

Purnomo, A. (2019a). Berpulang. In Syair Nimala. Sumenep: STIEBA Madura Press.

Purnomo, A. (2019b). Menyala. In Tenta Kimaya. Sumenep: STIEBA Madura Press.

Purnomo, A. (2019c). Rindu di Ubun-Ubun. In

Rassana Jlantir. Sumenep: STIEBA Madura

Press.

Purnomo, A., \& Asitah, N. (2019a). Bapak Samsuri.

In Dhalubang Marta. Sumenep: STIEBA Madura Press.

Purnomo, A., \& Asitah, N. (2019b). Cantik. In Lembhar Jiwana. Sumenep: STIEBA Madura Press.

Purnomo, A., \& Asitah, N. (2019c). Pandai. In

Tolesan Aditi. Sumenep: STIEBA Madura Press.

Purnomo, A., \& Asitah, N. (2019d). Sepekan Awal

Tanpamu. In Arebhan Helai. Sumenep: STIEBA Madura Press. 
Purnomo, A., \& Asitah, N. (2019e). Tangisnya. In

Bhumi Bawera. Sumenep: STIEBA Madura Press.

Purnomo, A., \& Rosyidah, E. (2019). Kita. In Suweda

Ate. Sumenep: STIEBA Madura Press. 